\title{
Characterization of Estuarine and Fluvial Dissolved Organic Matter by Thermochemolysis using Tetramethylammonium Hydroxide
}

\section{Charakterisierung von fluviogenen und ästuarstämmigen gelösten organischen Wasserinhaltsstoffen durch Thermochemolyse mit Tetramethylammoniumhydroxid}

\author{
J. D. H. van Heemst ${ }^{1}$, J. C. del Rio ${ }^{2}$, \\ P. G. Hatcher ${ }^{2,3}$, and J. W. de Leeuw ${ }^{1}$
}

Keywords: Dissolved Organic Matter, DOM, Ultrafiltration, Thermochemolysis, Tetramethylammonium Hydroxide, Lignin, Aromatic Acid, Cutan

Summary: Selected samples of dissolved organic matter (DOM) isolated by ultrafiltration (UDOM) have been analyzed by thermochemolysis in the presence of tetramethylammonium hydroxide (TMAH). This technique cleaves ester and ether bonds of bio- and geological macromolecules and releases monomer subunits and methylates them in situ as their methyl ethers and methyl esters. Compared with conventional pyrolysis, TMAH thermochemolysis avoids decarboxylation of preexisting carboxylic moieties and produces aromatic acids as their methyl esters. Various phenolic derivatives, which might originate from incorporated lignin-derived structures, from the highly aliphatic and resistant biopolymer cutan and also from proteinaceous materials, were identified among the products produced from UDOM upon thermochemolysis. The presence of lignin derivatives in UDOM indicates input of organic matter derived from terrestrial sources. Various aromatic acids, perhaps representing the final steps in the oxidation of the side-chain during microbial oxidation of lignin, were released upon TMAH thermochemolysis, suggesting they are structural constituents of the UDOM. Different ratios of lignin-derived materials, commonly determined using the $\mathrm{CuO}$ oxidation method, such as the $\Lambda$ value, indicative of the amount of lignin present, the acid/aldehyde ratio $(A d / A l)_{\mathrm{G}}$, indicative of the extent of oxidative degradation of the lignin component, and the syringyl/guaiacyl $(S / G)$ and $p$-hydroxyphenyl/guaiacyl $(P / G)$ ratios, indicative of the contribution for the different types of lignin, were determined.

Ir. Jasper D. H. van Heemst, Prof. Dr. Jan W. de Leeuw, Department of Marine Biogeochemistry and Toxicology, Netherlands Institute for Sea Research (NIOZ), P.O. Box 59, 1790 AB Den Burg, The Netherlands

Prof. Patrick G. Hatcher Ph.D., Dr. Jose C. del Rio, Department of Geosciences, 209 Academic Projects Building, The Pennsylvania State University, University Park, PA 16802, U.S.A.

Prof. Patrick G. Hatcher Ph.D., Fuel Science Program, Department of Material Science and Engineering, 209 Academic Projects Building, The Pennsylvania State University, University Park, PA 16802, U.S.A.

Correspondence to J. D. H. van Heemst, Department of Chemistry - Box 149, The Ohio State University, 120 W. 18th Avenue, Columbus, Ohio 43210-1153, U.S.A.

E-mail: jvanheem@chemistry.ohio-state.edu
Schlagwörter: gelöste organische Wasserinhaltsstoffe, DOM, Ultrafiltration, Thermochemolyse, Tetramethylammoniumhydroxid, Lignin, aromatische Säure, Cutan

Zusammenfassung: Durch Ultrafiltration isolierte gelöste organische Wasserinhaltsstoffe (UDOM - dissolved organic matter isolated by ultrafiltration) wurden durch Thermochemolyse mit Tetramethylammoniumhydroxid (TMAH) analysiert. Mit dieser Technik werden Ester- und Etherbindungen in Makromolekülen biologischer und geologischer Herkunft gespalten, die monomeren Untereinheiten freigesetzt und in situ zu Methylestern bzw. Methylethern methyliert. Anders als bei der herkömmlichen Pyrolyse unterbleibt bei der TMAHThermochemolyse die Decarboxylierung von carboxylischen Moleküleinheiten, stattdessen werden aromatische Säuren zu den Methylestern methyliert. Unter den ThermochemolyseProdukten der UDOM wurden verschiedene phenolische Derivate identifiziert, die von ligninstämmigen Strukturen, dem stark aliphatischen und stabilen Biopolymer Cutan oder auch von proteinartigen Substanzen herrühren können. Die Anwesenheit von Ligninderivaten in den UDOM deutet auf organische Substanzen terrestrischer Herkunft hin. Bei der TMAHThermochemolyse wurden verschiedene organische Säuren freigesetzt, was darauf hindeutet, dass sie strukturelle Bestandteile der UDOM sind. Möglicherweise handelt es sich um Endstufen der Seitenkettenoxidation bei der biologischen Oxidation von Lignin. Verschiedene, sonst mit der $\mathrm{CuO}$ Methode bestimmte Ligninparameter wurden ermittelt: der $\Lambda$-Wert als Maß für den Ligninanteil, das Säure-Aldehyd-Verhältnis $(A d / A l)_{\mathrm{G}}$ als Maß für den Fortgang des oxidativen Abbaus der Ligninkomponenten sowie das SyringaalkoholGuaiacol-Verhältnis $(S / G)$ und das $p$-HydroxyphenolGuaiacol-Verhältnis $(P / G)$ als Maß für den Anteil verschiedener Lignin-Typen.

\section{Introduction}

Structural characterization of complex organic matter such as dissolved organic matter (DOM) in natural water is a challenging task. The bulk of DOM in toto can nondestructively be examined by spectroscopic methods such as UV [1], IR and NMR. Solid-state ${ }^{13} \mathrm{C}$ NMR of isolated, macromolecular 
fractions of DOM makes it feasible to identify relative contributions of specific carbon types [2-4]. Studies to date have shown that XAD resin isolated material from oceanic DOM is very aliphatic in nature, while similar isolates of DOM from rivers is more aromatic in nature $[3,5]$. This represents the added contribution of terrestrial organic matter to river water DOM, which indeed tends to have a more aromatic character [4]. This type of organic matter also appears to have a high proportion of oxygen-containing functional groups such as carboxyl, alkoxyl and carbonyl groups. This high functionality probably contributes greatly to its solubility characteristics and to its affinity to adsorption by resins.

However, degradative methods need to be applied for more detailed information on the structure of DOM at a molecular level [6]. Wet chemical degradation techniques, such as the alkaline $\mathrm{CuO}$ method are able to identify components derived from lignin moieties [7], but these structures are present in only minor amounts in DOM [5]. Pyrolytic degradation coupled to gas chromatography-mass spectrometry has also provided important information regarding the chemical structure of humic fractions of DOM [8] and other fractions of DOM, isolated using tangential-flow ultrafiltration $[9,10]$. However, the major fraction of the DOM, probably much larger than $50 \%$, still remains poorly characterized.

Recently, a new technique involving thermochemolysis in the presence of tetramethylammonium hydroxide (TMAH) has been introduced by Challinor [11] for the characterization of polar macromolecules. This technique has also been applied in many other studies to characterize geo- and biopolymers [12-19] and humic materials [20-23]. The technique yields the methyl esters of carboxylic acids and methylates compounds containing hydroxyl groups, yielding products volatile enough for gas chromatographic analyses. TMAH thermochemolysis has also been applied for structural characterization of lignins $[13,14,24,25]$. $\beta-\mathrm{O}-4$ ether bond cleavage of the lignin macromolecule by TMAH produces lignin unit derivatives, that subsequently become methylated as was shown by Morrison and Mulder [26] and Mulder et al. [27]. Use of this thermochemolysis technique for the analysis of polar macromolecules rich in lignin moieties, such as humic substances and coals, has greatly enhanced product yields and produces methyl esters of carboxylic acids, not observed by conventional pyrolysis $[15,18,20,22]$. This technique has recently been used to examine a DOM sample obtained from a leachate of Juncus effusus L. [28] yielding primarily methylated derivatives of lignin-derived phenols.

A similar suite of products have been encountered by Hatcher and Clifford [20] and Clifford et al. [14] at both subpyrolysis reaction temperatures $\left(300^{\circ} \mathrm{C}\right.$ and $\left.310^{\circ} \mathrm{C}\right)$ and pyrolysis temperatures $\left(610^{\circ} \mathrm{C}\right.$ and $\left.700^{\circ} \mathrm{C}\right)$ indicating that the lower temperature is sufficient to yield product monomers with TMAH. In a recent paper by McKinney et al. [16] an off-line procedure is described for the TMAH thermochemolysis of the lignin macromolecule at $300^{\circ} \mathrm{C}$ using sealed glass ampoules. TMAH thermochemolysis at sub-pyrolysis temperatures causes ether bond cleavage in lignin producing lignin-derived compounds in a more gentle way than the alkaline $\mathrm{CuO}$ oxidation procedure, which also involves carbon-carbon bond cleavage [29].

The focus of this paper centers on demonstrating the value of the TMAH thermochemolysis as a rapid, low-cost, and easily implemented technique to detect and characterize traces of lignin and/or lignin moieties in some estuarine and fluvial DOM samples from three different regions in the world.
TMAH thermochemolysis has been applied to DOM samples in previous studies by del Rio et al. [19] and del Rio and Hatcher [23]. However, only qualitative data were shown in these studies. In the present study we provide quantitative data for various monomer constituents of DOM derived from lignin. Furthermore, the present study contains ultrafiltered DOM samples (UDOM) taken throughout a salinity gradient in an estuary. This allows us to examine the difference between pure riverine UDOM and riverine/seawater UDOM.

\section{Experimental}

Table 1 reflects a description of UDOM samples selected for this study. Samples were obtained from Galveston Bay (Texas, USA) and the Ems-Dollart Estuary (at the border of The Netherlands and Germany) by tangential-flow ultrafiltration [2, 30-32]. DOM from the Suwannee River (Georgia, USA) was obtained by reverse osmosis [33] and was kindly provided by E. M. Perdue. UDOM samples $(1 \ldots 2 \mathrm{mg})$ were weighed and placed in glass ampoules with $100 \mu \mathrm{L}$ of TMAH ( $25 \%$ in methanol) added. Methanol was evaporated under vacuum. Ampoules were sealed under vacuum and subsequently placed in an oven at $250^{\circ} \mathrm{C}$ for 30 minutes. After cooling, the tubes were cracked open and inside surfaces were extracted using methylene chloride $(3 \times 1 \mathrm{~mL})$. The combined extracts were reduced to dryness under a stream of nitrogen and dissolved in $25 \mu \mathrm{L}$ of methylene chloride, which contained an internal standard (575 ng $n$-icosane).

Table 1: List and description of the UDOM samples selected for this study.

Aufstellung der untersuchten durch Ultrafiltration isolierten organischen Wasserinhaltsstoffe (UDOM).
Sample name
Description

Suwannee River

Galveston Bay

Ems-Dollart Estuary (E1) UDOM isolated from the Ems-

Ems-Dollart Estuary (E2) UDOM isolated from the Ems-

Dollart Estuary (at salinity $1.5 \%$ )

Ems-Dollart Estuary (E3) UDOM isolated from the EmsDollart Estuary (at salinity 20\%o)

$1 \mu \mathrm{L}$ of the sample was analyzed by capillary gas chromatography. Gas chromatographic analyses were performed using a Hewlett-Packard 5890A gas chromatograph, equipped with a $30 \mathrm{~m}$ fused silica capillary column coated with chemically bound DB-5 $(0.25 \mathrm{~mm}$ i.d., film thickness $0.25 \mu \mathrm{m})$. Helium was used as a carrier gas with a flow rate of about $1 \mathrm{~mL} / \mathrm{min}$. A flame ionization detector (FID) at $300^{\circ} \mathrm{C}$ was used for detection. The GC was temperature programmed as follows: injection temperature $60^{\circ} \mathrm{C}$; first heating rate $15^{\circ} \mathrm{C} / \mathrm{min}$ to $150^{\circ} \mathrm{C}$; second heating rate $4^{\circ} \mathrm{C} / \mathrm{min}$ to a final temperature of $280^{\circ} \mathrm{C}$.

Gas chromatography-mass spectrometry (GC-MS) was carried out in the same manner as the GC analyses to allow for peak identification. A Kratos MS-80 RFA high-resolution gas chromatograph-mass spectrometer was used for separation and detection. Mass spectra were obtained at a scan rate of $0.6 \mathrm{~s}$ per decade of mass with a $0.2 \mathrm{~s}$ magnet settling time added. Compounds were identified comparing their mass spectra and relative retention times. Most of the peaks were identified by comparison with the Wiley/NBS library. However, some were confirmed by comparison with authentic standards. Mass spectra of many of the lignin deriv- 
atives having methoxylated side-chains were not included in the library. In these cases, identification is tentative and based only on analysis of the fragmentation patterns.

A single response factor was used for all lignin-derived compounds. This response factor was calculated by taking the average of the response factors of the commercial standards di- and trimethoxybenzaldehyde and di- and trimethoxybenzoic acid methyl ester relative to the standard. Evaluating the results of thermochemolysis it has to be kept in mind that the chemolysis products represent only a fraction of the original organic matter since the yield of the thermochemolysis reaction is far from $100 \%$. This is also true for conventional pyrolysis. Most of the advantages and disadvantages of analytical pyrolysis are described in [34].

The $\Lambda$ parameter, described by Hedges and Mann [35] for the alkaline $\mathrm{CuO}$ oxidation procedure is used to calculate the quantity of lignin monomers released from a sample in order to estimate the total amount of lignin present. This parameter was calculated by normalizing the sum of the total amount of lignin-derived compounds per $100 \mathrm{mg}$ of organic carbon in the sample. Ratios of carboxylic acid-containing guaiacyl phenols to aldehyde-containing guaiacyl phenols, $(A d / A l)_{\mathrm{G}}$, were calculated in a manner similar to that described by Ertel and Hedges [36]. These ratios were obtained by dividing the amount of 3,4-dimethoxybenzoic acid methyl ester by the amount of 3,4-dimethoxybenzaldehyde in the different samples. A similar ratio could be calculated for syringyl phenols, but low amounts of syringyl-type compounds precluded calculation of a useful $(A d / A l)_{\mathrm{S}}$. Syringyl/guaiacyl $(S / G)$ ratios were calculated from the sum of amounts of compounds containing a syringyl structure divided by the sum of amounts of compounds containing a guaiacyl structure. Finally, $p$-hydroxyphenyl/guaiacyl $(P / G)$ ratios were calculated from the sum of amounts of compounds containing a $p$-hydroxyphenyl structure relative to amounts of compounds containing a guaiacyl structure.

\section{Results and Discussion}

Chromatograms of the products released by TMAH thermochemolysis of the UDOM samples are shown in Figures 1-2. Many lignin-derived phenolic compounds are encountered among the thermochemolysis reaction products. These compounds mainly originate from the cleavage of the $\beta-\mathrm{O}-4$ bonds from incorporated lignin-derived moieties. These reaction products are similar to those produced upon on-line TMAH thermochemolysis of pure lignin or wood samples [14, 25]. The compounds, identified in the thermochemolyzates of the different samples, that have lignin-related structures, are listed in Table 2. Methylated derivatives of the three different lignin phenol subunits ( $p$-hydroxyphenyl, guaiacyl and syringyl) were present in the thermochemolyzates. Likewise, several other di- and trimethoxybenzenes, which are not lignin-derived structures were also encountered in the thermochemolyzates (Table 3).

In comparison to conventional pyrolysis, TMAH thermochemolysis avoids decarboxylation of pre-existing carboxylic moieties by methylating them, thus forming methyl esters. The major components identified in all selected UDOM samples were benzoic acid derivatives of guaiacyl (3,4-dimethoxybenzoic acid methyl ester, G6) and syringyl (3,4,5-trimethoxybenzoic acid methyl ester, S6) derivatives. The latter product could also be derived from hydrolyzable tannin derivatives. 4-Methoxybenzoic acid methyl ester (P6) was also encountered in several of the samples albeit in minor amounts. In DOM from decomposing Juncus effusus upon on-line TMAH thermochemolysis, benzoic acid derivatives have also been identified as major compounds [28]. The presence of methyl esters of these methoxybenzoic acids in the thermochemo- lyzates of the studied UDOM samples suggests that these samples may contain lignin-derived moieties, which have been oxidized at the a-carbon of the side chain of the lignin subunit. Lignin polymers may be attacked by microbial enzymes which selectively oxidize the $\alpha$-carbon in the side-chain [37]. Several other aromatic acid derivatives, having the carboxyl group at the $\beta$ - and $\gamma$-carbons of the side chain of the lignin subunit, such as the phenylacetic acid derivatives, 4-methoxyphenylacetic acid methyl ester (P24), 3,4-dimethoxyphenylacetic acid methyl ester (G24), 3,4,5-trimethoxyphenylacetic acid methyl ester (S24) and 3,4-dimethoxyphenylpropanoic acid methyl ester (G12), were also detected in some of the studied UDOM samples. Propenoic acid derivatives (from cinnamyl phenols) such as 4-methoxyphenylpropenoic acid methyl ester (P18) and the 3,4-dimethoxyphenylpropanoic acid methyl ester (G18), indicative of the presence of non-woody vascular plants, were also encountered.

Pyrolysis-GC and pyrolysis-GC-MS studies on the same UDOM samples from the Ems-Dollart Estuary as used in this study did not reveal the presence of methoxyphenols or dihydroxybenzenes, characteristic compounds from lignins and degraded lignins [38]. Instead, a series of alkylphenols, which have been related to some extent to the presence of algal polyphenolic macromolecules [10] and proteinaceous organic matter [39], were encountered in the pyrolyzates of these UDOM samples. It is therefore likely that the contribution of polyphenolic macromolecules from non-lignin moieties to UDOM in the Ems-Dollart Estuary is far more important than from lignin moieties derived of vascular plants. It is likely that compounds arising from the pyrolysis of lignin moieties remain practically undetected by conventional pyrolysis due to their low concentration. TMAH thermochemolysis on the other hand, exclusively cleaves hydrolyzable ester bonds and some labile ether bonds, such as the $\beta-\mathrm{O}-4$ bonds in lignin macromolecules. Therefore, it probably does not chemically attack the other polyphenolic macromolecules and releases predominantly the different lignin monomers.

In Table 4, a variety of parameters is listed that allow a quantitative description of the lignin content in the samples used in this study. Yields of TMAH thermochemolysis products derived from lignin moieties were used to determine values of $\Lambda$. Degraded wood samples may yield $\Lambda$ values that are representative for pure lignin. McKinney and Hatcher [40] have determined $\Lambda$ values of 19 and 24 for Holocene samples of a degraded Douglas fir and a degraded Taxonium stem, respectively. If we assume that these samples were composed of pure lignin, the $\Lambda$ value for pure lignin may be the average of these two values, i.e. 22 . Therefore, the $\Lambda$ value for the UDOM sample from the Suwannee River of 0.20 may represent a lignin content of $0.91 \%(\mathrm{w} / \mathrm{w})(100 \% \cdot 0.20 / 22)$. The range in $\Lambda$ values for the selected UDOM samples (Table 4) of $0.13 \ldots 0.94$ may thus represent a range of lignin contents of $0.59 \ldots 4.3 \%(\mathrm{w} / \mathrm{w})$, suggesting that lignin moieties, although present in the selected UDOM samples, are not major contributors to the bulk of the UDOM. This may explain why these lignin moieties are difficult to detect by conventional spectroscopic or pyrolytic methods [38].

$\Lambda$ values determined for XAD DOM isolates from lakes, using the alkaline $\mathrm{CuO}$ oxidation method, are between 2.5 and 3.4, for DOM from the Amazon River between 0.9 and 2.1 and for DOM from seawater between 0.11 and $0.19[5,36]$. The $\Lambda$ values for the samples of UDOM used in this study and calculated from TMAH thermochemolysis are between 0.13 and 0.94 . The $\Lambda$ values for UDOM from Suwannee River $(0.20)$ and the 

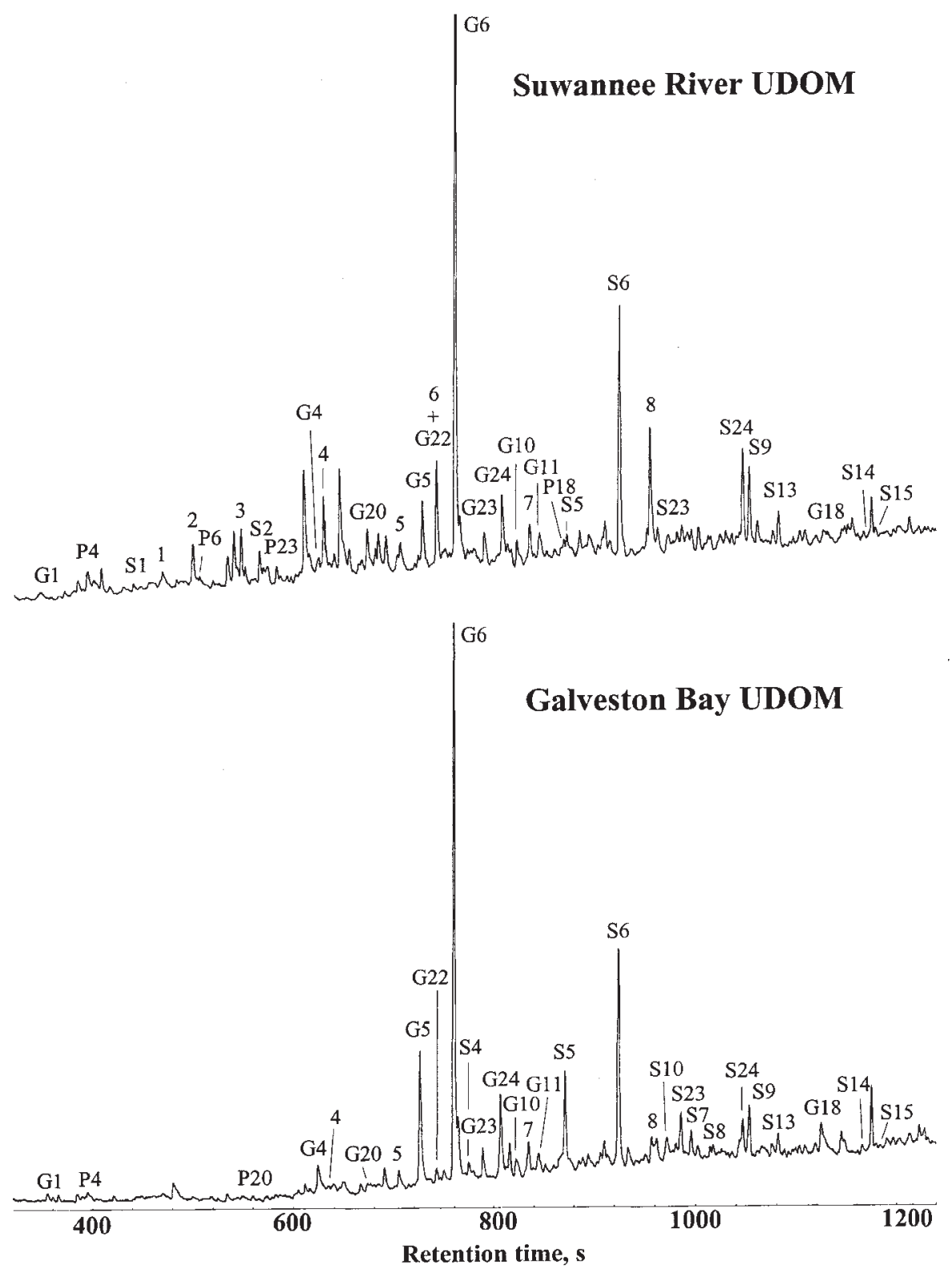

Fig. 1: Gas chromatograms of the TMAH thermochemolysis products released from UDOM from the Suwannee River and Galveston Bay. For peak identifications refer to Table 2 and 3.

Gaschromatogramme der aus den UDOMProben des Suwannee River und des Galveston Bay freigesetzten TMAH-Thermochemolyse-Produkte. Zuordnung der Peaks siehe Tabellen 2 und 3.
Ems-Dollart (0.46, 0.94 and 0.46) fall well within the range of $\Lambda$ values observed in other studies for XAD isolates of DOM from seawater and Amazon River water. The $\Lambda$ value for Galveston Bay UDOM (0.13) corresponds to the $\Lambda$ of DOM from seawater.

These low $\Lambda$ values $(0.13 \ldots 0.94)$ and the estimated values for lignin contents $(0.59 \ldots 4.3 \%)$ for the selected UDOM samples are in agreement with the conclusions of Opsahl and Benner [41], who have shown recently that the percentage of terrigenous organic matter is only $0.7 \ldots 2.4 \%$ of total DOM in the ocean. These values were calculated from yields of phenolic products using the alkaline $\mathrm{CuO}$ oxidation of UDOM samples concentrated by tangential-flow ultrafiltration. McCarthy et al. [42] concluded that the major part of UDOM consists of polysaccharide material from marine origin.

Ratios of vanillic acid/vanillin $(A d / A l)_{\mathrm{G}}$ are indicative of the amount of oxidative degradation of the lignin component $[36,43]$. A linear correlation exists between $(A d / A l)_{\mathrm{G}}$ ratios calculated using alkaline $\mathrm{CuO}$ oxidation and ratios calculated using TMAH thermochemolysis, but the TMAH thermochemolysis technique is possibly a more sensitive indicator of lignin degradation due to its larger dynamic range for $(A d / A l)_{\mathrm{G}}$ ratios [29]. For samples of fresh, undegraded vascular plant tissues (wood), $(A d / A l)_{\mathrm{G}}$ ratios calculated from TMAH thermochemolysis are typically less than 1 . Characteristic $(A d / A l)_{\mathrm{G}}$ ratios of samples of microbially degraded woods, however, are higher than 1, sometimes even higher than 10. In UDOM samples studied here, the $(A d / A l)_{\mathrm{G}}$ ratios are between 8.4 and 13.8 (Table 4), suggesting a high extent of oxidative degradation of lignin moieties present in DOM. These data are consistent with the alkaline $\mathrm{CuO}$ oxidation data on DOM samples examined by Meyers-Schulte and Hedges [5] and Ertel et al. [36], who also calculated relatively high $(A d / A l)_{\mathrm{G}}$ ratios for DOM. Del Rio et al. [19] calculated a $(A d / A l)_{\mathrm{G}}$ ratio of 4.1 for a DOM sample from the North Pacific Ocean by TMAH thermochemolysis. They found a general trend in $(A d / A l)_{\mathrm{G}}$ ratios in the Gulf of Mexico DOM samples, from a relatively low $(A d / A l)_{\mathrm{G}}$ ratio for two off-shore DOM samples (5.1 in both cases) and a relatively high $(A d / A l)_{\mathrm{G}}$ ratio for a near-shore sample (9.5). A simi- 


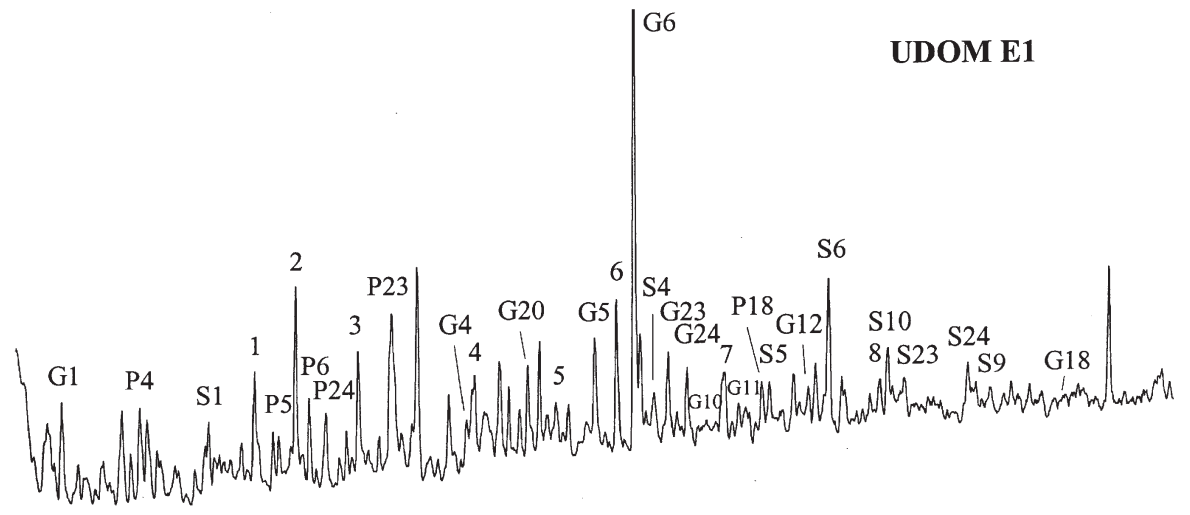

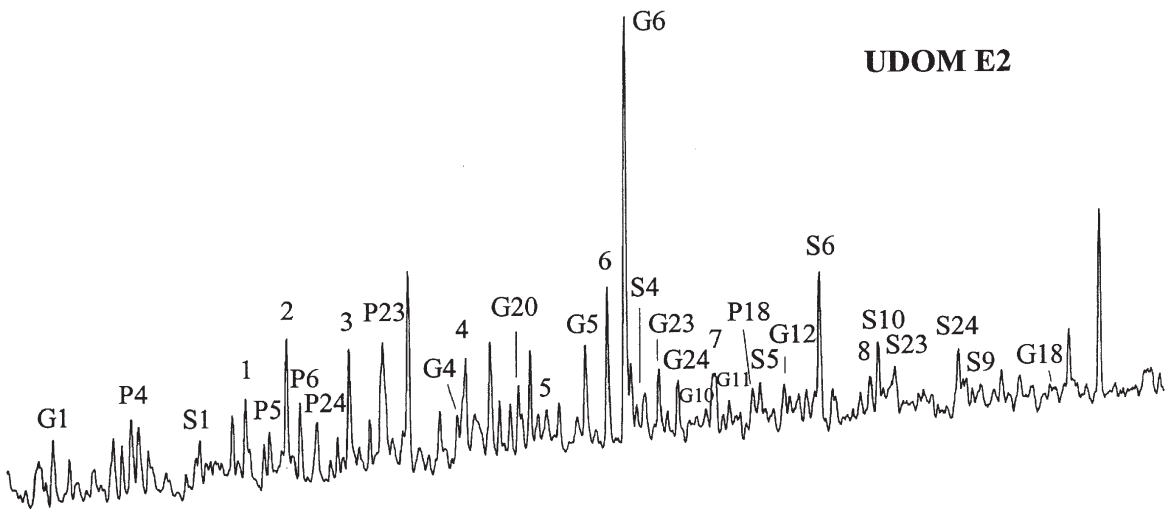

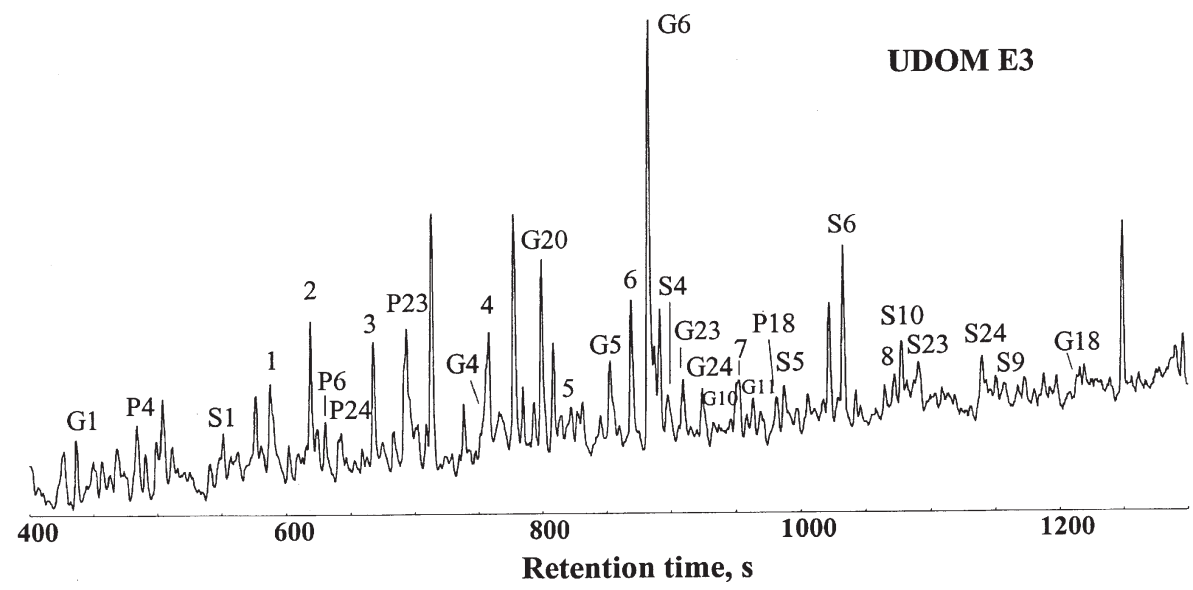

Fig. 2: Gas chromatograms of the TMAH thermochemolysis products released from UDOM from the Ems-Dollart estuary (E1, E2, E3). For peak identifications refer to Table 2 and 3.

Gaschromatogramme der aus den UDOMProben des Ems-Dollart-Ästuars (E1, E2, E3) freigesetzten TMAH-Thermochemolyse-Produkte. Zuordnung der Peaks siehe Tabellen 2 und 3. lar trend is observed for samples from the Ems-Dollart estuary, which is also in agreement with the diagenetic nature of Ems-Dollart UDOM [38].

Gymnosperm lignin is a dehydrogenation polymer of coniferyl alcohol monomer units (the precursor of guaiacyl $(G)$ units in lignin). Angiosperm lignin is a mixed dehydrogenation polymer of coniferyl and sinapyl (the precursor of syringyl (S) units in lignin) alcohols and grass lignin is composed of a mixed dehydrogenation polymer of coniferyl, sinapyl and $p$ coumaryl (the precursor of $p$-hydroxyphenyl (P) units in lignin) alcohols [37]. Therefore, low syringyl/guaiacyl ratios $(S / G)$ for all UDOM samples indicate the contribution to the UDOM samples studied of either both angiosperm and gymnosperm lignin, or of a highly degraded form of angiosperm lignin. Low $p$-hydroxyphenyl/guaiacyl $(P / G)$ ratios for all UDOM samples indicate that the contribution of lignin from non-woody plants to the UDOM samples studied has been minor. The ranges found for these parameters are also in the range of the values reported for various DOM samples using the $\mathrm{CuO}$ oxidation method [5].

Phenol derivatives which have an attached methoxylated $\mathrm{C}_{3}$ side chain (i.e. compounds P20, P23, G10/11, G20, G23, S7/8, S9/13, S10/11, S14/15, S23), present in the thermochemolyzates of the studied UDOM samples may be related to lignin moieties preserved in the UDOM. TMAH thermochemolysis induces cleavage of ether bonds and methylation of hydroxyl groups attached to the side chain of the lignin moieties. This means that the backbone of the side chain units is preserved during thermochemolysis, in contrast to the alkaline $\mathrm{CuO}$ oxidation procedure, which causes cleavage of these side chains from the lignin units. Two isomers (threo/erythro) of 1-(3,4,5-trimethoxyphenyl)-1,2,3-trimethoxypropane $(\mathbf{S 1 4} / \mathbf{1 5})$ have been identified in the thermochemolyzates of Suwannee River and Galveston Bay UDOM. The $\mathrm{C}_{3}$ side chains of these compounds are fully methoxylated and completely preserved. Thus, these compounds are unambiguously 
Table 2: Compounds identified in the UDOM samples. In den UDOM-Proben identifizierte Verbindungen.

\section{$p$-Hydroxyphenyl derived compounds}

P4 4-methoxybenzaldehyde

P5 4-methoxyacetophenone

P6 4-methoxybenzoic acid methyl ester

P18 4-methoxyphenylpropenoic acid methyl ester

P20 4-methoxyphenylmethanol methyl ether

P23 1-(4-methoxyphenyl)-2-methoxypropane

P24 4-methoxyphenylacetic acid methyl ester

Guaiacyl derived compounds
G1 1,2-dimethoxybenzene
G4 3,4-dimethoxybenzaldehyde
G5 3,4-dimethoxyacetophenone
G6 3,4-dimethoxybenzoic acid methyl ester
G10 cis-1-(3,4-dimethoxyphenyl)-methoxyprop-1-ene
G11 trans-1-(3,4-dimethoxyphenyl)-methoxyprop-1-ene
G12 3,4-dimethoxyphenylpropanoic acid methyl ester
G18 3,4-dimethoxyphenylpropenoic acid methyl ester
G20 3,4-dimethoxyphenylmethanol methyl ether
G22 1-(3,4-dimethoxyphenyl)-2-propanone
G23 1-(3,4-dimethoxyphenyl)-2-methoxypropane
G24 3,4-dimethoxyphenylacetic acid methyl ester

Syringyl derived compounds

S1 1,2,3-trimethoxybenzene

S2 3,4,5-trimethoxytoluene

S4 3,4,5-trimethoxybenzaldehyde

S5 3,4,5-trimethoxyacetophenone

S6 3,4,5-trimethoxybenzoic acid methyl ester

S7 cis-1-(3,4,5-trimethoxyphenyl)-2-methoxyethylene

S8 trans-1-(3,4,5-trimethoxyphenyl)-2-methoxyethylene

S9 cis-1-(3,4,5-trimethoxyphenyl)-3-methoxyprop-1-ene

S10 cis-1-(3,4,5-trimethoxyphenyl)-methoxyprop-1-ene

S11 trans-1-(3,4,5-trimethoxyphenyl)-methoxyprop-1-ene

S13 trans-1-(3,4,5-trimethoxyphenyl)-3-methoxyprop-1-ene

S14 threo/erythro 1-(3,4,5-trimethoxyphenyl)-1,2,3-trimethoxypropane

S15 threo/erythro 1-(3,4,5-trimethoxyphenyl)-1,2,3-trimethoxypropane

S22 1-(3,4,5-trimethoxyphenyl)-2-propanone

S23 1-(3,4,5-trimethoxyphenyl)-2-methoxypropane

S24 3,4,5-trimethoxyphenylacetic acid methyl ester

Table 3: Other phenolic compounds identified in the UDOM samples.

Weitere in den UDOM-Proben identifizierte phenolische Verbindungen.

1 3-methoxybenzoic acid methyl ester (isomer of P6)

2 1,2,4-trimethoxybenzene (isomer of S1)

3 1,3,5-trimethoxybenzene (derived from cutan)

4 2,4,6-trimethoxytoluene (derived from cutan)

5 1-(dimethoxyphenyl)-methoxypropane (isomer of $\mathbf{G 2 3}$ )

6 3,5-dimethoxybenzoic acid methyl ester (derived from cutan)

7 methyl, dimethoxybenzoic acid methyl ester

8 methoxybenzenedicarboxylic acid dimethyl ester

Table 4: Lignin parameters for the selected UDOM samples.

Lignin-Parameter für die ausgewählten UDOM-Proben. related to relatively unaltered lignin moieties, present in the UDOM.

Some of the phenol-derivatives that have been assigned to lignin moieties may also have alternative origins, such as proteins, tannins and cutans. Such methylated phenolic derivatives, that were encountered after TMAH thermochemolysis of the studied UDOM samples, are 1,3,5-trimethoxybenzene (3) and 2,4,6-trimethoxytoluene (4). These compounds are probably not derived from lignin. They have recently been identified as major components in TMAH thermochemolyzates of cutan [44], a highly aliphatic, resistant biopolymer present in leaf cuticles from certain plants [45]. 3,5-Dimethoxybenzoic acid methyl ester (6), identified in some of the studied UDOM samples, has also been identified in the TMAH thermochemolyzates of cutan. Therefore, the presence of these characteristic compounds in the thermochemolyzates of the studied UDOM samples may be related to the presence of degradation products from this other higher plant biopolymer (i.e. cutan).

\section{Conclusions}

The procedure described herein provides a simple method to evaluate the lignin content of UDOM that can be easily implemented in any laboratory having standard gas chromatographic facilities. A significant feature of this method is that it may be able to trace lignin inputs where extensive degradation has occurred and resulted in sufficient alteration of lignin. Compared to conventional pyrolysis methods for organic matter characterization, TMAH thermochemolysis avoids decarboxylation of pre-existing carboxylic moieties and releases aromatic acids as methyl esters. High amounts of aromatic acids were released from all the UDOM samples analyzed here. The aromatic acids released from UDOM after TMAH thermochemolysis probably represent compounds produced in the final steps of lignin side-chain oxidation during microbial degradation and are thought to be pristine components of the macromolecular structure of UDOM. Although it is not known at this point whether these aromatic acids are present in ester linkages or free, it is very likely that any lignin moiety that is entrained within UDOM would have a significant amount of free carboxyl functionality which would account for its solubility. Characteristic compounds arising from the highly aliphatic and resistant biopolymer cutan, present in the leaf cuticle of some plants, were also detected. This indicates that portions of this higher plant biopolymer are a part of the UDOM structure.

\section{Acknowledgements}

We thank E.M. Perdue (Georgia Tech) and Peter H. Santschi (Texas A\&M University) for providing UDOM samples. This work was partly supported by a grant from the National Science Foundation (OCE-9503257). We thank the Netherlands Organisation for Scientific Research (NWO) for providing a studentship to Jasper van Heemst. This is NIOZ contribution no. 3456 .

\begin{tabular}{lrrrrr}
\hline & Suwannee River & Galveston Bay & E1 & E2 & E3 \\
\hline$\Lambda$ & $0.20 \pm 0.01$ & $0.13 \pm 0.01$ & $0.46 \pm 0.02$ & $0.94 \pm 0.01$ & $0.46 \pm 0.01$ \\
$(A d / A l)_{\mathrm{G}}$ & $13.80 \pm 0.70$ & $12.00 \pm 1.00$ & $8.40 \pm 1.00$ & $10.50 \pm 0.70$ & $10.40 \pm 0.70$ \\
$S / G$ & $0.56 \pm 0.04$ & $0.49 \pm 0.03$ & $0.33 \pm 0.03$ & $0.45 \pm 0.05$ & $0.41 \pm 0.05$ \\
$P / G$ & $0.05 \pm 0.01$ & $0.04 \pm 0.01$ & $0.06 \pm 0.01$ & $0.06 \pm 0.01$ & $0.05 \pm 0.01$ \\
\hline
\end{tabular}




\section{References}

[1] Ludwig, U., Grischeck, T., Nestler, W., Neumann, V.: Behaviour of different molecular-weight fractions of DOC of Elbe river water during river bank filtration. Acta Hydrochim. Hydrobiol. 25, 145-150 (1997).

[2] Benner, R., Pakulsky, J. D., McCarthy, M., Hedges, J. I., Hatcher, P. G.: Bulk chemical characteristics of dissolved organic matter in the ocean. Science 255, 1561-1564 (1992).

[3] Hedges, J. I, Hatcher, P. G., Ertel, J. R., Meyers-Schulte, K.: A comparison of dissolved humic substances from seawater with Amazon River counterparts by ${ }^{13} \mathrm{C}-\mathrm{NMR}$ spectrometry. Geochim. Cosmochim. Acta 56, 1753-1757 (1992).

[4] Malcolm, R. L.: The uniqueness of humic substances in each of soil, stream and marine environments. Anal. Chim. Acta 232, 19-30 (1990).

[5] Meyers-Schulte, K. J., Hedges, J. I.: Molecular evidence for a terrestrial component of organic matter dissolved in ocean water. Nature 321, 61-63 (1986).

[6] Norwood, D. L.: Critical comparison of structural implications from degradative and nondegradative approaches. In: Frimmel, F. H., Christman, R. F. (Eds.): Humic substances and their role in the environment. John Wiley and Sons, New York, 1988, pp. 151-164.

[7] Hedges, J. I., Ertel, J. R.: Characterization of lignin by capillary chromatography of cupric oxide oxidation products. Anal. Chem. 54, 174-178 (1982).

[8] Abbt-Braun, G., Frimmel, F. H., Schulten, H.-R.: Structural investigations of aquatic humic substances by pyrolysis-field ionization mass spectrometry and pyrolysis-gas chromatography/mass spectrometry. Water Res. 23, 1579-1591 (1989).

[9] van Heemst, J. D. H., Baas, M., de Leeuw, J. W., Benner, R.: Molecular characterization of marine dissolved organic matter (DOM). In: Øygard, K. (Ed.): Organic Geochemistry. Falch Hurtigtrykk, 1993, pp. 694-698.

[10] van Heemst, J. D. H., Peulvé, S., de Leeuw, J. W.: Novel algal polyphenolic biomacromolecules as significant contributors to resistant fractions of marine dissolved and particulate organic matter. Org. Geochem. 24, 629-640 (1996).

[11] Challinor, J. M.: A pyrolysis-derivatization-gas chromatograph technique for the elucidation of some synthetic polymers. J. Anal. Appl. Pyrolysis 16, 323-333 (1989).

[12] de Leeuw, J. W., Baas, M.: The behaviour of esters in the presence of tetramethylammonium salts at elevated temperatures; flash pyrolysis or flash chemolysis? J. Anal. Appl. Pyrolysis 26, 175-184 (1993).

[13] Challinor, J. M.: Characterisation of wood by pyrolysis derivatisation-gas chromatography/mass spectrometry. J. Anal. Appl. Pyrolysis 35, 93-107 (1995).

[14] Clifford, D. J., Carson, D. M., McKinney, D. E., Bortiatynski, $J$. M., Hatcher, P. G.: A new rapid technique for the characterization of lignin in vascular plants: thermochemolysis with tetramethylammonium hydroxide (TMAH). Org. Geochem. 23, 169-175 (1995).

[15] Martin, F., Gonzalez-Vila, F. J., del Rio, J. C., Verdejo, T.: Pyrolysis derivatization of humic substances. 1. Pyrolysis of fulvic acids in the presence of tetramethylammonium hydroxide. J. Anal. Appl. Pyrolysis 28, 71-80 (1994).

[16] McKinney, D. E., Carson, D. M., Clifford, D. J., Minard, R. D., Hatcher, P. G.: Off-line thermochemolysis versus flash pyrolysis for the in situ methylation of lignins: Is pyrolysis necessary? J. Anal. Appl. Pyrolysis 34, 41-56 (1995).

[17] McKinney, D. E., Hatcher, P. G.: Characterization of peatified and coalified wood by tetramethylammonium hydroxide (TMAH) thermochemolysis. Int. J. Coal Geol. 32, 217-228 (1996).

[18] del Rio, J. C., Gonzalez-Vila, F. J., Martin, F., Verdejo, T.: Characterization of humic acids from low rank coals by ${ }^{13} \mathrm{C}-\mathrm{NMR}$ and pyrolysis-methylation. Formation of benzenecarboxylic acid moieties during coalification process. Org. Geochem. 22, 885-891 (1994).

[19] del Rio, J. C., McKinney, D. E., Knicker, H., Nanny, M. A., Minard, R. D., Hatcher, P. G.: Structural characterization of bio- and geo-macromolecules by off-line thermochemolysis with tetramethylammonium hydroxide. J. Chromatogr. A 823 , 433-448 (1998).

[20] Hatcher, P. G., Clifford, D. J.: Flash pyrolysis and in situ methylation of humic acids from soil. Org. Geochem. 21, 1081-1092 (1994).

[21] del Rio, J. C., Gonzalez-Vila, F. J., Martin, F., Verdejo, T.: Chemical structural investigation of asphaltenes and kerogens by pyrolysis-methylation. Org. Geochem. 23, 10091022 (1995).

[22] del Rio, J. C., Gonzalez-Vila, F. J., Martin, F.: Thermally assisted hydrolysis and alkylation as a novel pyrolytic approach for the structural characterization of natural biopolymers and geomacromolecules. Trends Anal. Chem. 15, 70-79 (1996).

[23] del Rio, J. C., Hatcher, P. G.: Structural characterization of humic substances using thermochemolysis with tetramethylammonium hydroxide. In: Gaffney, J. S., Marley, N. A., Clark, $S$. B. (Eds.): Humic and fulvic acids: isolation, structure, and environmental role. ACS Symposium Series 651, American Chemical Society, Washington DC, 1996, pp. 78-95.

[24] Martin, F., del Rio, J. C., Gonzalez-Vila, F. J., Verdejo, T.: Pyrolysis derivatization of humic substances. 2. Pyrolysis of soil humic acids in the presence of tetramethylammonium hydroxide. J. Anal. Appl. Pyrolysis 31, 75-83 (1995).

[25] Martin, F., del Rio, J. C., Gonzalez-Vila, F. J. and Verdejo, T.: Thermally assisted hydrolysis and alkylation of lignins in the presence of tetra-alkylammonium hydroxides. J. Anal. Appl. Pyrolysis 35, 1-13 (1995).

[26] Morrison III, W. H., Mulder, M. M.: Pyrolysis mass spectrometry and pyrolysis gas chromatography-mass spectrometry of ester-and-ether-linked phenolic acids in coastal bermudagrass cell walls. Phytochemistry 35, 1143-1151 (1994).

[27] Mulder, M. M., van der Hage, E. R. E., Boon, J. J.: Analytical in source pyrolytic methylation electron impact mass spectrometry of phenolic acids in biological matrices. Phytochem. Anal. 3, 165-172 (1992).

[28] Wetzel, R. G., Hatcher, P. G., Bianchi, T. S.: Natural photolysis by ultraviolet irradiance of recalcitrant dissolved organic matter to simple substrates for rapid bacterial metabolism. Limnol. Oceanogr. 40, 1369-1380 (1995).

[29] Hatcher, P. G., Nanny, M. A., Minard, R. D., Dible, S. C., Carson, D. M.: Comparison of two thermochemolytic methods for the analysis of lignin in decomposing gymnosperm wood: The $\mathrm{CuO}$ oxidation method and the method of thermochemolysis with tetramethylammonium hydroxide (TMAH). Org. Geochem. 23, 881-888 (1995).

[30] Benner, R.: Ultrafiltration for the concentration of bacteria, viruses, and dissolved organic matter. Marine Particles: Analysis and Characterization. Geophysical Monograph 63, 181-185 (1991).

[31] Dai, M., Buesseler, K. O., Ripple, P., Andrews, J., Belastock, R. A., Gustafsson, Ö., Moran, S. B.: Evaluation of two crossflow ultrafiltration membranes for isolating marine organic colloids. Mar. Chem. 62, 117-136 (1998).

[32] Guo, L., Santschi, P. H.: A critical evaluation of the cross-flow ultrafiltration technique for sampling colloidal organic carbon in seawater. Mar. Chem. 55, 113-127 (1996).

[33] Sun, L., Perdue, E. M., McCarthy, J. F.: Using reverse osmosis to obtain organic matter from surface and ground waters. Water Res. 29, 1471-1477 (1995).

[34] Saiz-Jimenez, C.: Analytical pyrolysis of humic substances: pitfalls, limitations and possible solutions. Environ. Sci. Technol. 28, 1773-1780 (1994).

[35] Hedges, J. I., Mann, D. C.: The characterization of plant tissues by their lignin oxidation products. Geochim. Cosmochim. Acta 43, 1803-1807 (1979).

[36] Ertel, J. R., Hedges, J. I., Perdue, E. M.: Lignin signature of aquatic humic substances. Science 223, 485-487 (1984).

[37] Crawford, R. L.: Lignin biodegradation and transformation. Wiley, New York, 1981.

[38] van Heemst, J. D. H., Megens, L., Hatcher, P. G., de Leeuw, $J$. W.: Nature, origin and age of estuarine ultrafiltered dissolved organic matter as determined by molecular and carbon isotope characterization, Org. Geochem., submitted.

[39] van Heemst, J. D. H., van Bergen, P. F., Stankiewicz, B. A., de Leeuw, J. W.: Multiple sources of alkylphenols produced 
upon pyrolysis of DOM, POM and recent sediments. J. Anal. Appl. Pyrolysis 52, 239-256 (1999).

[40] McKinney, D. E., Hatcher, P. G.: Characterization of peatified and coalified wood by tetramethylammonium hydroxide (TMAH) thermochemolysis. Int. J. Coal Geol. 32, 217-228 (1996).

[41] Opsahl, S., Benner, R.: Distribution and cycling of terrigenous dissolved organic matter in the ocean. Nature 386, 480-482 (1997).

[42] McCarthy, M., Hedges, J., Benner, R.: Major biochemical composition of dissolved high molecular weight organic matter in seawater. Mar. Chem. 55, 281-297 (1996).

[43] Ertel, J. R., Hedges, J. I.: Sources of sedimentary humic substances: vascular plant debris. Geochim. Cosmochim. Acta 49, 2097-2107 (1985).
[44] McKinney, D. E., Bortiatynski, J. M., Carson, D. M., Clifford, D. J., de Leeuw, J. W., Hatcher, P. G.: Tetramethylammonium hydroxide (TMAH) thermochemolysis of the aliphatic biopolymer cutan: insights into the chemical structure. Org. Geochem. 24, 641-650 (1996).

[45] Tegelaar, E. W., de Leeuw, J. W., Largeau, C., Derenne, S., Schulten, H.-R., Müller, R., Boon, J. J., Nip, M., Sprenkels, J. C. M.: Scope and limitations of several pyrolysis methods in the structural elucidation of a macromolecular plant constituent in the leaf cuticle of Agave americana L. J. Anal. Appl. Pyrolysis 15, 29-54 (1989).

received 17 May 1999

accepted 21 January 2000 